\title{
Material Erosion
}

National Cancer Institute

\section{Source}

National Cancer Institute. Material Erosion. NCI Thesaurus. Code C63208.

Problem associated with a progressive loss of a material from a solid surface. 